Original Paper http://ajol.info/index.php/ijbcs http://indexmedicus.afro.who.int

\title{
Microbiological and physico-chemical characterisation of well water in the town of Korhogo, Côte d'Ivoire
}

\author{
Ollo KAMBIRE ${ }^{*}$, Konan Mathurin YAO $^{1}$, Sampah Georges EBLIN ${ }^{2}$, \\ Diegon Arnaud Romain TOKPA ${ }^{1}$ and Rose KOFFI-NEVRY ${ }^{3}$ \\ ${ }^{1}$ Department of Biochemistry and Genetics, Peleforo Gon Coulibaly University, BP 1328 Korhogo, \\ Côte d'Ivoire. \\ ${ }^{2}$ Department of Earth Sciences, Laboratory of Environmental Science and Technology, Jean Lorougnon \\ Guede University, BP 150 Daloa, Cote d'Ivoire. \\ ${ }^{3}$ Laboratory of Biotechnology and Food Microbiology, Department of Food Science and Technology, \\ Nangui Abrogoua University, 02 BP 801 Abidjan, Côte d'Ivoire. \\ *Corresponding author; E-mail: kam_ollo@yahoo.fr
}

Received: 16-03-21

Accepted: $15-05-2021$

Published: 30-06-2021

\begin{abstract}
Water is essential to the life of every living organism. The water used by the consumer must be safe for the preservation of his health. The objective of this study was to assess the quality of well water used in households in the city of Korhogo. To do this, water samples were taken from the wells of different households. Parameters such as $\mathrm{pH}$, temperature, electrical conductivity and total dissolved solids were measured at the sampling sites. Nitrates and ammonium were determined by spectrophotometric methods using sodium salicylate and indophenol blue, respectively. The membrane filtration technique has been used for the enumeration of total coliforms, Escherichia coli, fecal enterococci, sulfite-reducing anaerobic bacteria, yeasts and moulds. The agar incorporation method was used for the enumeration of mesophilic aerobic germs. The non-conformity relative to $\mathrm{pH}$ was $73 \%$. All wells were contaminated with nitrates and ammonium. Non-compliance rates of $80 \%$ and $53 \%$ were obtained for nitrates and ammonium respectively. Non-compliance with mesophilic aerobic germs, total coliforms, E. coli and fecal enterococci was $100 \%$ for each indicator. No spore of sulphite-reducing clostridia has been identified. Contamination rates of $80 \%$ (mould) and $67 \%$ (yeast) were recorded. The moulds isolated from the various water samples belong to the genus Aspergillus. The quality of well water in households is not suitable for human consumption. These waters require treatment or household residents must switch to other safe sources of drinking water.
\end{abstract}

(C) 2021 International Formulae Group. All rights reserved.

Keywords: Groundwater, quality, contamination, household.

\section{INTRODUCTION}

In many parts of the world, especially in developing countries, water supply has become a key factor in public health and economic development (Hawa, 2002). Indeed, water is an indispensable natural resource for human, animal and plant life. Groundwater is a freshwater resource in rural communities. It accounts for about $97 \%$ of total continental freshwater (Bosca, 2002). According to Merzoug et al. (2010), 75-90\% of the world's population uses groundwater. 
Lack of safe water supply, hygiene and sanitation is the cause of many diseases (Kouassi et al., 2015). The WHO reported in 2003 that in developing countries, up to $80 \%$ of illnesses and more than a third of deaths are attributable to water-borne diseases. Gastroenteritis is the disease most frequently associated with the ingestion of faecally contaminated water and has very serious health consequences (Loyola et al., 2020). Other rarer diseases such as hepatitis or meningitis can also be caused by the ingestion of contaminated water.

In Africa, the quality of these waters is constantly threatened by factors such as uncontrolled urbanisation, high population growth and the lack of control over the quality of the environment. Thus, the water extracted from this resource may contain elements that can have undesirable effects on health, such as pathogenic microorganisms, undesirable substances or even toxic substances (Yapo et al., 2010). The degradation of the quality of these waters is linked to the infiltration of wastewater, the use of chemical fertilizers in agriculture, the presence of septic tanks, the lack of wastewater treatment, the lack of a sanitation system and the non-respect of public hygiene conditions.

The proportion of households with access to drinking water rose from $46 \%$ in 1998 to $51.2 \%$ in 2002 and to $61 \%$ in 2008 in Côte d'Ivoire (Kouassi et al., 2015). Climate change often plays a significant role in the issue of access to drinking water in many localities (Tall et al., 2012). The Poro Region is an area characterised by irregular rainfall and recurrent drought. As the rainfall deficit is weakly compensated for by the modern drinking water supply system and dams, people in this area still have recourse to well water as their main source for domestic needs (Yapo et al., 2016). In the city of Korhogo, several households own a well. The water from these wells is consumed by the inhabitants. During the dry season, even households with potable water turn to well water because of frequent interruptions in the water supply. The objective of this study was to assess the bacteriological and physicochemical quality of well water in households, with a view to preventing health problems associated with water consumption.

\section{MATERIALS AND METHODS \\ Presentation of the study area}

Korhogo is the fourth largest city in the country in terms of population and economy. Situated in the north of Côte d'Ivoire, between $10^{\circ} 41^{\prime}$ and $8^{\circ} 53^{\prime}$ north latitude and $5^{\circ} 30^{\prime}$ and $6^{\circ} 31^{\prime}$ west longitude (Figure 1), and $645 \mathrm{~km}$ from the economic capital (Abidjan), the city of Korhogo has a surface area of approximately $12500 \mathrm{~km}^{2}$ and an estimated population of 174000 inhabitants (Kouassi et al., 2015).

\section{Sampling}

The various water samples for this study were taken during the dry season precisely in the month of November 2020. During this season, frequent interruption of drinking water supply is observed in households, forcing residents to turn to well water. Five (05) neighbourhoods where well water consumption is important have been selected. They are "Tiekelezo", "Koko", "Soba", "Lognon" and "Sinistré". In each neighbourhood, three wells were randomly selected for water sampling, for a total of 15 wells. Recipients used by members of the household were used to collect water samples. The water samples for microbiological and physico-chemical analysis were taken from pre-sterilised borosilicate bottles and polyethylene bottles respectively. The various samples taken were immediately placed in a cooler containing the ice and transported to the laboratory for the various analyses.

\section{Physico-chemical analysis}

Temperature, Total Dissolved Solids, $\mathrm{pH}$ and electrical conductivity were measured on site using multi-parameter. The determination of ammonium was carried out by the indophenol blue method. In an alkaline medium and in the presence of nitroprusside which acts as a catalyst, the ammonium ions treated with a solution of chlorine and phenol give indophenol blue which can be dosed by colorimetry. Nitrates were determined by the spectrophotometric method with sodium 
salicylate. Nitrates give sodium paranitrosalicylate which is coloured yellow and can be dosed by colorimetry in the presence of sodium salicylate.

\section{Microbiological analysis}

The count of mesophilic aerobic germs was carried out by the technique of incorporation into the agar according to the AFNOR NF EN ISO 6222 standard. The counts of total coliforms, Escherichia coli, fecal enterococci, sulfite-reducing anaerobic bacteria, and yeasts and moulds were carried out using the filtration technique (Rodier et al., 2009). One hundred (100) $\mathrm{mL}$ of water from each sample was filtered through a sterile cellulose membrane (Sartorius Stedim Biotech, Germany) with a porosity of $0.45 \mu \mathrm{m}$ for the enumeration of coliforms, E. coli and faecal enterococci. For yeasts and moulds, 10 and 5 $\mathrm{mL}$ of water have been filtered. The enumeration of the spores of sulphite-reducing clostridia consisted of heating $60 \mathrm{~mL}$ of water at $80^{\circ} \mathrm{C}$ for 15 minutes to destroy the vegetative forms and filtering $50 \mathrm{~mL}$ of this water on a membrane with a porosity of $0.2 \mu \mathrm{m}$.
Total coliforms and E. coli were counted simultaneously on Rapid'Ecoli 2 agar (Bio-Rad, France). Confirmation of the presence of $E$. coli was carried out by the indole urea test. The media Slanetz and Bartley (Oxoid, UK), Dichloran Rose Bengal Chloramphenicol (Oxoid, UK) and TSN (BioRad, France) were used for the enumeration of fecal enterococci, yeasts, moulds and the spores of sulphite-reducing clostridia respectively. All inoculated Petri dishes were incubated at $37^{\circ} \mathrm{C}$.

After the purification of the mould strains, their identification was carried out on the basis of macroscopic and microscopic characters from the identification keys published by David Malloch translated and adapted by Lecomte (1997).

\section{Statistical analysis}

A normalized principal component analysis (NPCA) has been performed with the XLSTAT 2020 software. This analysis allowed to establish the correlations between the microbiological and physico-chemical parameters. The software also allowed to make the elementary statistics.

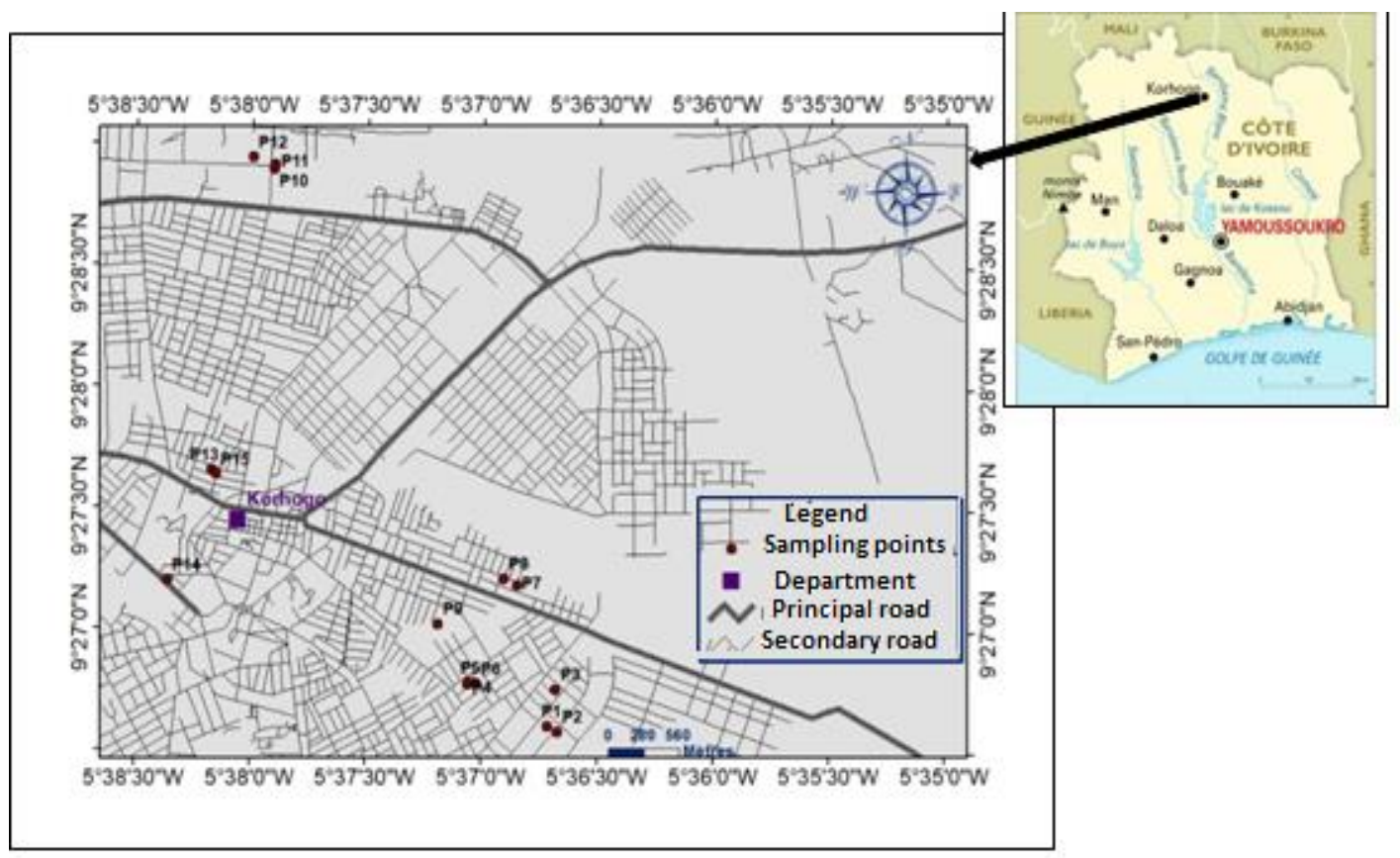

Figure 1: Sampling sites. 


\section{RESULTS}

\section{Microbiological analysis \\ Total coliforms}

The total coliform loads in the water from the various wells are between 1.1.10 ${ }^{2}$ and $2.3 .10^{2} \mathrm{cfu} / 100 \mathrm{~mL}$. Loads of the order of $2.10^{2}$ $\mathrm{cfu} / 100 \mathrm{~mL}$ were obtained in the wells of three of the five quarters (Table 1). These are the "Sinistré", "Lognon" and "Soba" neighbourhoods. Total coliforms were detected in the water from all wells. All loads of this bacterial group are above the guide value of 0 cfu/100 mL. The bacteriological quality of the water from the different wells with respect to this parameter is unsatisfactory (Table 2).

\section{Escherichia coli}

E. coli has been identified in the water from all wells. Loads ranged from 1 to 95 cfu/100 mL. The highest E. coli loads were obtained from wells in the "Lognon" neighbourhood (60-95 cfu/100 mL), followed by those in the "Koko" neighbourhood (44-90 cfu/100 mL) (Table 1). All loads are above the guide value which is $0 \mathrm{cfu} / 100 \mathrm{~mL}$. The water from all wells is of unsatisfactory bacteriological quality with respect to this species (Table 2).

\section{Fecal enterococci}

Fecal enterococci loads varied between 2 and $1.2 .10^{2} \mathrm{cfu} / 100 \mathrm{~mL}$. These bacteria are present in the water of all wells. This bacterial group has lower loads than total coliforms. On the whole, the highest loads were obtained in the wells in the "Sinistré" neighbourhood (Table 1). All fecal enterococci loads are above the guide value of $0 \mathrm{cfu} / 100 \mathrm{~mL}$, indicating that well water is not bacteriologically compliant with this bacterial group (Table 2).

\section{Mesophilic aerobic germs}

High loads of mesophilic aerobic germs were obtained in the water of all wells. These range from $10^{3}$ to $5.8 .10^{4} \mathrm{cfu} / 100 \mathrm{~mL}$. These germs are present in the water of all wells. The highest loads were recorded in "Lognon" wells $\left(6.9 .10^{3}-5.8 .10^{4} \mathrm{cfu} / 100 \mathrm{~mL}\right)$ followed by "Koko" wells $\left(1.7 .10^{3}-3.10^{4}\right.$ cfu/100 mL) (Table 1). All mesophilic aerobic germs loads are above the guide value of $20 \mathrm{cfu} / 100 \mathrm{~mL}$. The bacteriological quality of the water from the different wells is not satisfactory (Table 2).

\section{Spores of sulphite-reducing clostridia}

No spores of sulphite-reducing clostridia was detected in the water from all wells sampled (Tables 1).

\section{Yeasts and moulds}

Yeast and mould loads in the water of the various wells are recorded in Table 1. Mould loads are between 0 and $80 \mathrm{cfu} / 100 \mathrm{~mL}$. Moulds were detected in the water from the three wells in the "Koko" neighbourhood comparatively to the wells in the other four neighbourhoods where moulds were identified in two out of three wells. The yeast loads obtained are between 0 and $2.8 .10^{2} \mathrm{cfu} / 100$ $\mathrm{mL}$. No yeast has been identified in the well water of the "Soba" neighbourhood. In the neighbourhoods of "Tiekelezo" and "Lognon", yeast is present in the water of the three wells in each neighbourhood. The rates of presence of yeasts and moulds are $67 \%$ and $80 \%$ respectively (Table 2).

\section{Characterization of moulds}

The isolated mould strains belong to the genus Aspergillus. A total of five different strains of Aspergillus (sp1 to sp5) have been identified (Table 3).

\section{Physico-chemical analysis}

The results of the different physicochemical parameters of the water from the different wells are presented in Table 4. 
$p H$

The water from the various wells is acidic. The $\mathrm{pH}$ values of the water from these wells are between 5.81 and 6.9. The water from wells in the "Sinistré" neighbourhood is more acidic compared to that from wells in other neighbourhoods. Several wells have $\mathrm{pH}$ values (73\%) that do not comply with guidelines (6.59.5) (Table 5).

\section{Temperature}

Recorded temperatures range from 27.9 ${ }^{\circ} \mathrm{C}$ to $31.3{ }^{\circ} \mathrm{C}$. The variation of temperature from one well to another is small. The highest temperature $\left(31.3^{\circ} \mathrm{C}\right)$ was obtained in a well of the "Soba" neighbourhood.

\section{Electrical conductivity}

The electrical conductivities measured in the water of the various wells are between 160 and $1020 \mu \mathrm{S} / \mathrm{cm}$ with an average of 536 $\mu \mathrm{S} / \mathrm{cm}$. Overall, the highest electrical conductivities $\quad(950-1020 \mu \mathrm{S} / \mathrm{cm}) \quad$ were obtained in the water from the wells of "Koko" neighbourhood, followed by "Soba" neighbourhood wells with conductivities ranging from 780 to $980 \mu \mathrm{S} / \mathrm{cm}$. The electrical conductivities are below the guideline (Table $5)$.

\section{Total Dissolved Solids}

For the different wells, concentrations of total dissolved solids (TDS) ranging from 80 to $510 \mathrm{mg} / \mathrm{L}$ were obtained. The highest TDS values $(470-510 \mathrm{mg} / \mathrm{L})$ were obtained in the well water of the "Koko" neighbourhood followed by the well water of the "Soba" neighbourhood (390-490 mg/L).

\section{Ammonium}

The concentrations of ammonium in the water of the various wells are between 0.04 and
$2.71 \mathrm{mg} / \mathrm{L}$. Overall, the highest concentrations $(2.45-2.71 \mathrm{mg} / \mathrm{L})$ were measured in the well water of the "Koko" neighbourhood. All the concentrations recorded in the wells in this neighbourhood are above the guideline of 0.5 $\mathrm{mg} / \mathrm{L}$. Two wells in "Tiekelezo", one well in "Lognon" and "Koko" have ammonium concentrations below the guideline. The water from all the wells in the "Sinistré" neighbourhood have ammonium concentrations below the guide value. A total of $53 \%$ of the wells are non-compliant (Table 5).

\section{Nitrate}

The water in the various wells has nitrate concentrations ranging from 9.43 to $114.89 \mathrm{mg} / \mathrm{L}$. All wells in the "Sinistré" and "Koko" neighbourhoods with 91.35-114.3 $\mathrm{mg} / \mathrm{L}$ and 89.91-114.89 $\mathrm{mg} / \mathrm{L}$ respectively showed nitrate concentrations above the guideline of $50 \mathrm{mg} / \mathrm{L}$. Twelve of the 15 wells sampled have nitrate concentrations above the guide value, i.e. $80 \%$ non-compliance (Table $5)$.

\section{Statistical analysis}

Table 6 shows the correlations between microbiological and physico-chemical parameters. A strong correlation is observed between total coliform loads and E. coli, between mould loads and ammonium concentrations, between $\mathrm{pH}$ and nitrate and finally between conductivity and TDS. There is no correlation between bacterial loads (total coliforms, E. coli, fecal enterococci, GAM) and physico-chemical parameters. 
Table 1: Microorganism loads in well water.

\begin{tabular}{lllllllll}
\hline \multirow{2}{*}{ Neighbourhood } & Well & \multicolumn{7}{c}{ Microorganism loads (cfu/100 mL) } \\
\cline { 2 - 9 } Tiekelezo & CT & E. coli & Ent & GAM & SRC & Mois & Lev \\
\hline \multirow{5}{*}{ Sinistré } & P1 & $1.6 .10^{2}$ & 12 & 74 & $1.7 .10^{3}$ & $<1$ & $<1$ & $1.4 .10^{2}$ \\
& P3 & $1.1 .10^{2}$ & 1 & 71 & $8.2 .10^{3}$ & $<1$ & 20 & 20 \\
& P4 & $1.2 .10^{2}$ & 16 & 2 & $3.8 .10^{3}$ & $<1$ & 20 & 20 \\
\hline \multirow{5}{*}{ Lognon } & P5 & $2.1 .10^{2}$ & 64 & 70 & $8.5 .10^{3}$ & $<1$ & 20 & 20 \\
& P6 & $2.2 .10^{2}$ & 76 & $10^{2}$ & $5.5 .10^{3}$ & $<1$ & $<1$ & 20 \\
\cline { 2 - 9 } Soba & P7 & $2.3 .10^{2}$ & 95 & 56 & $6.9 .10^{3}$ & $<1$ & 40 & $2.8 .10^{2}$ \\
& P8 & $2.1 .10^{2}$ & 90 & 82 & $1.5 .10^{4}$ & $<1$ & $<1$ & 20 \\
& P9 & $1.6 .10^{2}$ & 60 & 92 & $5.8 .10^{4}$ & $<1$ & 20 & 20 \\
\cline { 2 - 9 } Koko & P10 & $2.10^{2}$ & 16 & 35 & $6.4 .10^{3}$ & $<1$ & $<1$ & $<1$ \\
& P11 & $1.9 .10^{2}$ & 30 & 22 & $4.2 .10^{3}$ & $<1$ & 40 & $<1$ \\
& P12 & $2.1 .10^{2}$ & 38 & 25 & $8.3 .10^{3}$ & $<1$ & 60 & $<1$ \\
\cline { 2 - 9 } & P13 & $2.10^{2}$ & 90 & 23 & $1.5 .10^{4}$ & $<1$ & 80 & $2.8 .10^{2}$ \\
& P14 & $1.2 .10^{2}$ & 44 & 23 & $1.7 .10^{3}$ & $<1$ & 40 & 20 \\
& P15 & $2.2 .10^{2}$ & 88 & $1.2 .10^{2}$ & $3.10^{4}$ & $<1$ & 60 & $<1$ \\
\hline
\end{tabular}

CT : Total coliforms; Ent : Fecal enterococci; GAM : Mesophilic aerobic germs ; Mois : Moulds ; lev : yeasts ; SRC : spore of sulphite-reducing clostridia.

Table 2: Statistical summary of microorganism loads.

\begin{tabular}{lccccc}
\hline Microorganisms & $\begin{array}{c}\text { Minimum } \\
(\mathbf{u f c / 1 0 0} \mathbf{~ m L})\end{array}$ & $\begin{array}{c}\text { Maximum } \\
(\mathbf{u f c / 1 0 0} \mathbf{~ m L})\end{array}$ & $\begin{array}{c}\text { Average } \\
(\mathbf{u f c / 1 0 0 ~} \mathbf{~ m L})\end{array}$ & $\begin{array}{c}\text { Council Directive } \\
\mathbf{9 8 / 8 3 / E C}(\mathbf{u f c / 1 0 0} \mathbf{~ m L})\end{array}$ & $\begin{array}{c}\text { Non-compliance } \\
\text { rate (\%) }\end{array}$ \\
\hline CT & $1.1 .10^{2}$ & $2.3 .10^{2}$ & $1.8 .10^{2}$ & 0 & 100 \\
E. coli & 1 & 95 & 49 & 0 & 100 \\
Ent & 2 & $1.2 .10^{2}$ & 56 & 0 & 100 \\
GAM & $10^{3}$ & $5.8 .10^{4}$ & $1.1 .10^{4}$ & 20 & 100 \\
Mois & $<1$ & 80 & 28 & - & $80^{*}$ \\
Lev & $<1$ & 280 & 56 & - & $67^{*}$ \\
SRC & $<1$ & $<1$ & $<1$ & 0 & 0 \\
\hline
\end{tabular}

CT : Total coliforms; Ent : Fecal enterococci; GAM : Mesophilic aerobic germs ; Mois : Moulds ; Lev : yeasts ; SRC : spore of sulphite-reducing clostridia; *contamination rate. 
O. KAMBIRE et al. / Int. J. Biol. Chem. Sci. 15(3): 1264-1275, 2021

Table 3: Macroscopic and microscopic characteristics of isolated moulds.

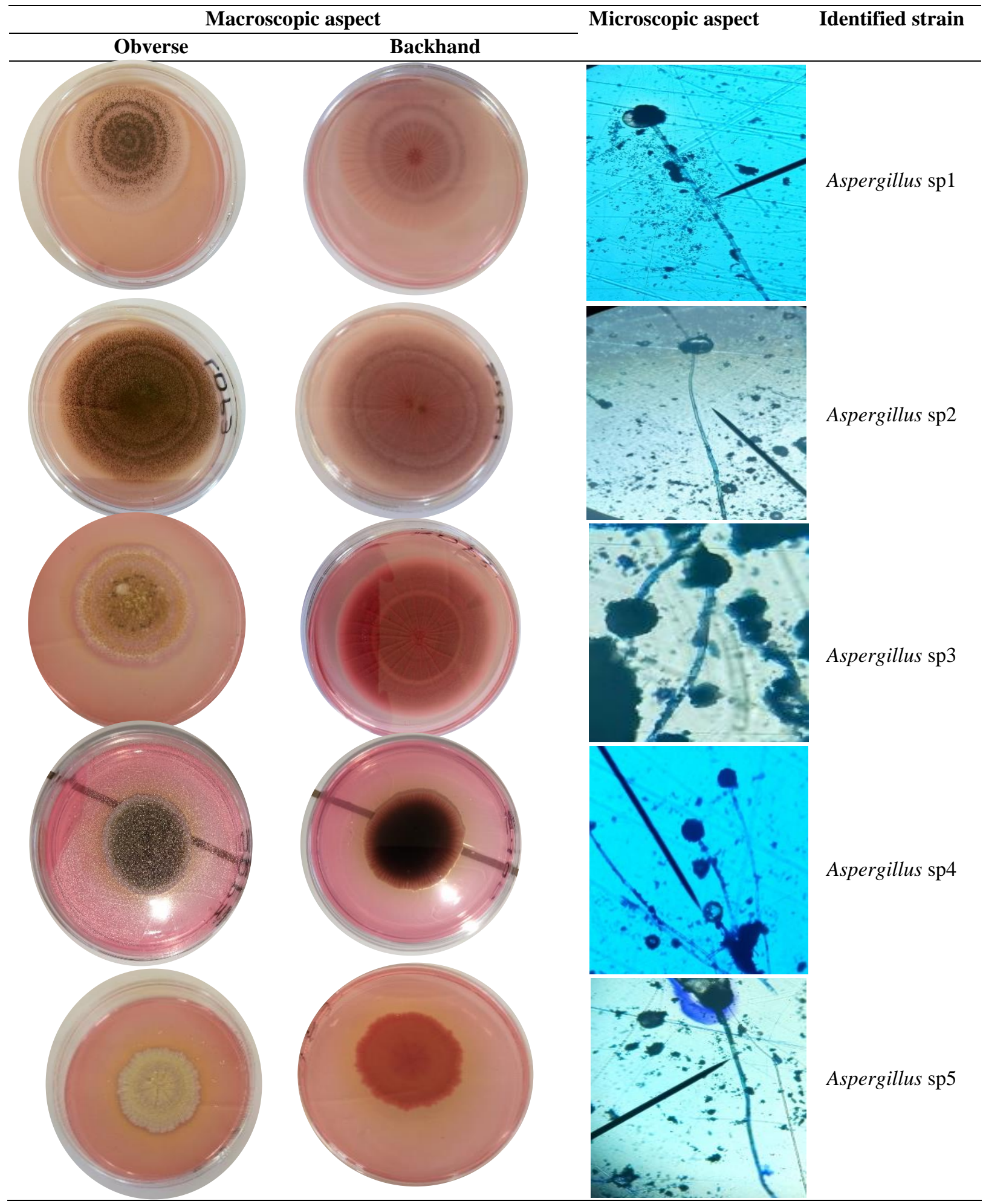


Table 4: Values of the physico-chemical parameters of well water.

\begin{tabular}{|c|c|c|c|c|c|c|c|}
\hline Neighbourhood & Well & $\mathbf{p H}$ & $\begin{array}{l}\text { Temp } \\
\left({ }^{\circ} \mathbf{C}\right)\end{array}$ & $\begin{array}{l}\text { EC } \\
\mu \mathrm{S} / \mathrm{cm}\end{array}$ & $\begin{array}{l}\text { TDS } \\
\mathrm{mg} / \mathrm{L}\end{array}$ & $\begin{array}{l}\text { Nit } \\
\mathrm{mg} / \mathrm{L}\end{array}$ & $\begin{array}{l}\mathrm{Am} \\
\mathrm{mg} / \mathrm{L}\end{array}$ \\
\hline \multirow{3}{*}{ Tiekelezo } & P1 & 6.62 & 28.7 & 190 & 100 & 9.5 & 0.04 \\
\hline & $\mathrm{P} 2$ & 6.30 & 28.9 & 550 & 270 & 96.82 & 2.66 \\
\hline & P3 & 6.32 & 29.1 & 210 & 100 & 101.88 & 0.05 \\
\hline \multirow{3}{*}{ Sinistré } & $\mathrm{P} 4$ & 6.15 & 28.9 & 270 & 130 & 98.21 & 0.1 \\
\hline & P5 & 5.81 & 28.8 & 300 & 150 & 91.35 & 0.16 \\
\hline & P6 & 5.91 & 29 & 160 & 80 & 114.3 & 0.04 \\
\hline \multirow{3}{*}{ Lognon } & P7 & 6.69 & 28.9 & 220 & 110 & 87.34 & 2.51 \\
\hline & P8 & 6.76 & 28.9 & 360 & 180 & 43.09 & 0.06 \\
\hline & P9 & 6.42 & 29 & 210 & 100 & 94.81 & 2.31 \\
\hline \multirow[b]{2}{*}{ Soba } & P10 & 5.91 & 28.6 & 780 & 390 & 114.06 & 0.52 \\
\hline & P11 & 6.27 & 31.3 & 850 & 420 & 113.12 & 1.02 \\
\hline \multirow{4}{*}{ Koko } & $\mathrm{P} 12$ & 6.90 & 27.9 & 990 & 490 & 9.43 & 0.04 \\
\hline & P13 & 6.45 & 29.2 & 950 & 470 & 89.91 & 2.71 \\
\hline & P14 & 6.02 & 29.5 & 1020 & 510 & 91.02 & 2.69 \\
\hline & P15 & 6.25 & 28.5 & 980 & 490 & 114.89 & 2.45 \\
\hline
\end{tabular}

Temp : temperature ; EC : electrical conductivity ; TDS : Total Dissolved Solids; Nit : nitrate ; Am : ammonium.

Table 5: Statistical summary of physico-chemical parameters.

\begin{tabular}{lccccc}
\hline Parameters & Minimun & Maximun & Average & Council Directive 98/83/EC & $\begin{array}{c}\text { Non-compliance } \\
\text { rate (\%) }\end{array}$ \\
\hline pH & 5.8 & 6.9 & 6.3 & $6.5-9.5$ & 73 \\
Temp $\left({ }^{\circ} \mathbf{C}\right)$ & 27.9 & 31.3 & 29 & - & - \\
$\mathbf{E C}(\boldsymbol{\mu S} / \mathbf{c m})$ & 160 & 1020 & 536 & 2500 & 0 \\
TDS $(\mathbf{m g} / \mathbf{L})$ & 80 & 510 & 266 & - & - \\
$\mathbf{N i t}(\mathbf{m g} / \mathbf{L})$ & 9.43 & 114.89 & 84.65 & 50 & 80 \\
$\mathbf{A m}(\mathbf{m g} / \mathbf{L})$ & 0.04 & 2.71 & 1.16 & 0.5 & 53 \\
\hline
\end{tabular}

Temp. : temperature ; EC : electrical conductivity ; TDS: total dissolved solids ; Nit : nitrate ; Am : ammonium 
Table 6: Correlation matrix between physico-chemical and microbiological parameters.

\begin{tabular}{|c|c|c|c|c|c|c|c|c|c|c|c|c|}
\hline Variables & CT & E. coli & Ent & GAM & Mois & Lev & $\mathbf{p H}$ & Temp & Cond & TDS & Nit & Am \\
\hline CT & 1 & & & & & & & & & & & \\
\hline E. coli & 0.707 & 1 & & & & & & & & & & \\
\hline Ent & 0.148 & 0.173 & 1 & & & & & & & & & \\
\hline GAM & 0.476 & 0.384 & 0.386 & 1 & & & & & & & & \\
\hline Mois & -0.108 & 0.104 & -0.291 & 0.166 & 1 & & & & & & & \\
\hline Lev & 0.021 & 0.152 & 0.057 & 0.052 & -0.069 & 1 & & & & & & \\
\hline pH & 0.174 & 0.091 & -0.024 & 0.206 & 0.129 & 0.240 & 1 & & & & & \\
\hline Temp & -0.133 & 0.010 & -0.239 & -0.198 & 0.169 & -0.039 & -0.218 & 1 & & & & \\
\hline EC & 0.023 & 0.080 & -0.116 & 0.115 & 0.473 & -0.399 & 0.009 & 0.119 & 1 & & & \\
\hline TDS & 0.027 & 0.084 & -0.109 & 0.112 & 0.464 & -0.395 & 0.007 & 0.115 & 1.000 & 1 & & \\
\hline Nit & -0.034 & 0.010 & -0.079 & 0.122 & 0.190 & -0.203 & -0.726 & 0.419 & 0.047 & 0.042 & 1 & \\
\hline Am & -0.218 & 0.036 & 0.184 & 0.385 & 0.569 & 0.302 & 0.033 & 0.159 & 0.398 & 0.396 & 0.349 & 1 \\
\hline
\end{tabular}

\section{DISCUSSION}

Microbiological analysis of well water in the city of Korhogo shows a strong contamination of this resource. All wells were contaminated with mesophilic aerobic germs. This result is close to that of Soncy et al. (2015). Indeed, these authors reported a noncompliance of $99 \%$ of the wells due to the presence of mesophilic aerobic germs in Togo. All loads obtained in this study are above the guide value and are within the range of loads reported by previous authors. Lalami et al. (2014) also reported GAM loads above the guide value in well water in Morocco. The GAM constitute the global microbial flora present on a given surface. These germs are of various origins (environment, humans...) and are likely to contaminate the water.

Total coliforms were enumerated in all water samples indicating non-compliance of these waters. This result corroborates that of Ouattara et al. (2016) on the quality of drinking water in the locality of N'Zianouan and the precarious neighbourhoods of Abidjan. E. coli, a species of the coliform group has also been identified in the waters of all the wells. This result still shows non-compliance of well water and corroborates that of Camara (2011). According to this author, the various bacteriological analysis carried out for drinking water points in Africa show that most traditional wells and water sources are polluted. Total coliforms are present in animal waste but also in the environment. Both sources can contribute to the contamination of well water. However, with the presence of $E$. coli and fecal enterococci (bacteria living in the intestines of mammals) in well water, the contamination would be more of animal origin. The lack of correlation between bacteria and nitrogen salts indicates that these do not come from infiltration septic systems. Withdrawal of water using a container most often left on the ground could be the main vector for contamination of well water (Mwanza et al., 2019). According to Chippaux et al. (2002), 
contamination of wells by total and fecal coliforms, E. coli and fecal enterococci generally occurs when people draw from wells. In contrast to the study by Bengoumi et al. (2015), no spore of sulphite-reducing clostridia was obtained in this study. The presence of sulphite-reducing Clostridium in the water reflects old or intermittent fecal pollution.

Fungi (moulds, yeasts) have been found in well water. The mould strains isolated belong to Aspergillus. These results corroborate those of Melle (2010). Indeed, moulds of the genus Aspergillus and Microsporum and yeasts of the genus Candida were isolated from well water in Algeria by this author. The fungi are present in the soil and in the air. Despite the protection of the sampled wells, they could be contaminated by airborne spores when the water is drawn from the well. In addition to the high loads of microorganisms recorded, abnormal physico-chemical parameters were also detected.

The water from the various wells is acidic with $\mathrm{pH}$ values between 5.81 and 6.9. This result is identical to that reported by Yapo et al. (2016) on the study of groundwater in the same area. According to Ahoussi et al. (2013), acidity is one of the essential characteristics of waters in Côte d'Ivoire. The temperatures obtained (27.9-31.3 $\left.{ }^{\circ} \mathrm{C}\right)$ are close to those of Yao et al. (2012) in groundwater in southwestern Côte d'Ivoire. According to Camara (2011), water with a temperature between 28 ${ }^{\circ} \mathrm{C}$ and $32{ }^{\circ} \mathrm{C}$ is a good culture medium for environmental micro-organisms. The electrical conductivities measured in the water of the various wells are between 160 and $1020 \mu \mathrm{S} / \mathrm{cm}$ with an average of $536 \mu \mathrm{S} / \mathrm{cm}$. These electrical conductivities are higher than those of Yapo et al. (2016). According to the classification proposed by Detay (1993), mineralization is important in the water of the wells in the "Koko" and "Soba" neighbourhoods. Except for two wells (low mineralization), the mineralization of the water in the wells of the other three neighbourhoods ("Tiekelezo,
"Sinistré", "Lognon") is average. The strong correlation between TDS and electrical conductivity indicates an identical variation for these two parameters. Nitrogen salts (nitrates and ammonium) are present in all wells. Nitrate concentrations in $80 \%$ of the wells and ammonium concentrations in $53 \%$ of the wells are above the guide values. This result confirms the high contamination of these two indicators in Abidjan wells reported by Yapo et al. (2010). These results underline the strong anthropic pressure that the water from these various wells is undergoing. Anthropogenic sources of this pollution include fertilizers, wastewater, animal waste and septic tanks (Aka et al., 2013; Lagnika et al., 2014). According to Yapo et al. (2010), pollution factors arise from major problems related to lack of sanitation (lack of appropriate sanitation for groundwater protection). Water pollution from the wells analyzed could be related to the infiltration of wastewater from septic systems present in all homes.

\section{Conclusion}

The objective of this study was to assess the microbiological and physico-chemical quality of well water in households, with a view to preventing health problems associated with water consumption in the city of Korhogo. The study found that the well water in the households did not comply with the microbiological criteria. Apart from the spore of sulphite-reducing clostridia all bacteriological indicators (total coliforms, E. coli, fecal enterococci, GAM) are present in all wells. Moulds of the genus Aspergillus were identified in $80 \%$ of the wells. All wells are contaminated with ammonium and nitrate ions. The non-compliance rates for these nitrogen salts were $80 \%$ and $53 \%$ respectively for nitrate and ammonium ions. A 73\% rate of well noncompliance was recorded for $\mathrm{pH}$. The water from the wells of Korhogo is not suitable for human consumption, it requires treatment. 


\section{COMPETING INTERESTS}

The authors declare that they have no competing interests.

\section{AUTHORS' CONTRIBUTIONS}

OK: Data analysis and writing. DART: sampling and data acquisition. KMY: experimental design and document revision. SGE: map elaboration and revision of the physico-chemical part. RKN: contribution to the proofreading of the manuscript.

\section{ACKNOWLEDGEMENTS}

The authors would like to thank the inhabitants of the households for their understanding when taking the water samples.

\section{REFERENCES}

Ahoussi KE, Koffi YB, Kouassi AM, Soro G, Biémi J. 2013. Etude hydrochimique et microbiologique des eaux de source de l'Ouest montagneux de la Côte d'Ivoire : cas du village de Mangouin-Yrongouin (sous-préfecture de Biankouman). $J$. Appl. Biosci., 63: 4703-4719.

Aka N, Bamba SB, Soro G, Soro N. 2013. Etude hydrochimique et microbiologique des nappes d'altérites sous climat tropical humide : cas du Département d'Abengourou (Sud-Est de la Côte d'Ivoire). Larhyss Journal, 16 : 31-52.

Bengoumi D, ChahlaouI A, Belghiti L, Taha I, Samih M, El Moustaine R. 2015. Etude de la qualité bactériologique de l'eau de certains puits dans les élevages avicole (Meknes et Gharb-Maroc). Larhyss Journal, 24: 209-226.

Camara O. 2011. Pollution microbiologique des eaux souterraines dans le quartier Tanghin de Ouagadougou : états des lieux et perspectives. Mémoire de Master, Institut international d'ingénierie de l'eau et de l'environnement, Burkina Faso, 67p.

Chippaux JP, Houssier S, Groos P, Bouvier C, Brissaud F. 2002. Etude de la pollution de l'eau souterraine de la ville de Niamey,
Niger. Bull. Soc. Pathol. Exot., 95(2): 119-123.

Detay M. 1993. Le Forage d'Eau ; Réalisation, Entretien et Réhabilitation. Éditions Masson, Paris.

Hawa S. 2002. Analyse physico-chimique et bactériologique au L.N.S. des eaux de consommation de la ville de Bamako durant la période 2000 et 2001 . Thèse de Doctorat d'état en Pharmacie, Université de Bamako, Mali, 77 p.

Kouassi MR, Koné B, Yao KE, Silué B, Cissé G, Soro N. 2015. Approvisionnement en eau potable, qualité de la ressource et risques sanitaires associés à Korhogo (Nord Côte d'Ivoire). Environ Risque \& Santé, 14(3): 230-241. DOI: 10.1684/ers.2015.0781

Lagnika M, Ibikounle M, Montcho J-PC, Wotto VD, Sakiti NG. 2014. Caractéristiques physico-chimiques de l'eau des puits dans la commune de Pobè (Bénin, Afrique de l'Ouest). J. Appl. Biosci., 79: 6887-6897. DOI: http://dx.doi.org/10.4314/jab.v79i1.13

Lalami AEO, EL-Akhal F, Berrada S, Bennani L, Raiss N, Maniar S. 2014. Evaluation de la qualité hygiénique des eaux de puits et de sources par l'utilisation d'une analyse en composantes principales (ACP) : une étude de cas de la région de Fès (MAROC). J. Mater. Environ. Sci., 5(S1): 2333-2344.

Lecomte M. 1997. La détermination des moisissures (Deutéromycètes). Université de Toronto, Toronto, $36 \mathrm{p}$.

Loyola S, Sanchez JF, Maguiña E, Canal E, Castillo R, Bernal M, Meza Y, Tilley DH, Oswald WE, Heitzinger K, Lescano AG, Rocha CA. 2020. Faecal contamination of drinking water as associated with diarrheal pathogen carriage among children younger than 5 years in three Peruvian rural communities. Am. J. Trop. Med. Hyg., 102(6): 1279-1285. DOI:10.4269/ajtmh.19-0337 
Melle AA. 2010. Microbiologie et physicochimie de l'eau des puits et des sources de la région de Guelma (Nord-Est de l'Algérie). Mémoire de Magister, Université de Guelma, Algérie, 124 p.

Merzoug D, Khiari A, Aït Boughrous A, Boutin C. 2010. Faune aquatique et qualité de l'eau des puits et sources de la région d'Oum-El-Bouaghi (Nord-Est algérien). Hydroécol. Applied, 17: 77-97. DOI:

https://doi.org/10.1051/hydro/2010001

Mwanza PB, Katond JP, Hanocq P. 2019. Evaluation de la qualité physico chimique et bactériologique des eaux de puits dans le quartier spontané de Luwowoshi (RD Congo). Tropicultura, 37(2): 15. DOI: 10.25518/2295-8010.627

Ouattara A, Meite A, Dally T, Ouattara H, Kati-Coulibaly S. 2016. Étude de la qualité des eaux de consommation dans la localité de N'Zianouan s/p de Tiassalé et des quartiers précaires de trois communes du District d'Abidjan (Koumassi, Treichville, Attécoubé). J. Appl. Biosci., 102: 9708-9715. DOI: http://dx.doi.org/10.4314/jab.v102i1.5

Rodier J, Legube B, Merlet N. 2009. L'Analyse de l'Eau ( $9^{\mathrm{e}}$ édn). Dunod, Paris.

Soncy K, Djeri B, Anani K, Eklou-Lawson M, Adjrah Y, Karou DS, Ameyapoh Y, De Souza C. 2015. Evaluation de la qualité bactériologique des eaux de puits et de forage à Lomé, Togo. J. Appl. Biosci., 91:
8464-8469.

DOI:

http://dx.doi.org/10.4314/jab.v91i1.6

Tall A, Simon JM, Maarten VA, Suarez P, AitChellouche Y, Diallo AA, Braman L. 2012. Using seasonal climate forecasts to guide disaster management: the Red Cross experience during the 2008 West Africa floods. International Journal of Geophysics, 2012: $12 . \quad$ DOI: $10.1155 / 2012 / 986016$

Yao TK, Oga M-S, Fouché O, Baka D, Pernelle C, Biémi J. 2012. Evaluation de la potabilité chimique des eaux souterraines dans un bassin versant tropical : cas du Sud-Ouest de la Côte d'Ivoire. Int. J. Biol. Chem. Sci., 6(6): 7069-7086. DOI: 10.4314/ijbcs.v6i6.42

Yapo OB, Mambo V, Seka A, Ohou MJA, Konan F, Gouzile V, Tidou AS, Kouame KV, Houenou P. 2010. Evaluation de la qualité des eaux de puits à usage domestique dans les quartiers défavorisés de quatre communes d'Abidjan (Côte d'Ivoire) : Koumassi, Marcory, PortBouet et Treichville. Int. J. Biol. Chem. Sci., 4(2): 289-307. DOI: 10.4314/ijbcs.v4i2.58111

Yapo RI, Mambo V, Alder AC, Ohou-Yao MJ, Ligban R, Dao D, Stamm C, Bonfoh B. 2016. Caractérisation saisonnière des eaux de puits à usage maraîchère et domestique de Korhogo (Côte d'Ivoire). Int. J. Biol. Chem. Sci., 10(3): 1433-1449. DOI: $10.4314 /$ ijbcs.v10i3.41 